\title{
ANALISIS TINGKAT RISIKO PROYEK PELAKSANAAN PEMELIHARAAN JALAN UNTUK MENINGKATKAN KINERJA MUTU PROYEK JALAN DI KABUPATEN MALANG
}

\author{
Robertus Tri Bowo Nyata Utama ${ }^{*}$, Edhi Wahjuni Setyowati ${ }^{2}$, Harimurti $^{3}$ \\ 1Mahasiswa / Magister / Teknik Sipil / Universitas Brawijaya \\ 2 Dosen / Teknik Sipil / Universitas Brawijaya \\ 3 Dosen / Teknik Sipil / Universitas Brawijaya \\ Korespondensi: robertusutama@gmail.com
}

\begin{abstract}
In every road maintenance project implementation there are always unpredictable risks affecting the quality of the project performance. This study aims to obtain the most dominant risks affecting the quality performance of road maintenance projects in Malang Regency using Analysis Hierarchy Process (AHP) method and Multiple Linear Regression. The AHP method was chosen to observe the highest level of the risk, while the Multiple Linear Regression method was selected to find risk events which have significant effect upon the quality degradation of the project. The results showed that the risk of material specification insufficiency reaches the highest risk level with risk factor value of 0.584, while the risking events caused by materials and human resources insufficiency is the most significant influences affecting the quality degradation of the project performance.
\end{abstract}

Keywords: Road Maintenance project, Project Risk, Performance Quality

\section{PENDAHULUAN}

Pembangunan infrastruktur jalan adalah hal yang sangat penting sebagai pendukung utama dalam aktifitas ekonomi, baik yang terletak pada daerah Perkotaan, maupun pada daerah Kabupaten. Dalam beberapa tahun terakhir pemerintah Kabupaten Malang giat melakukan pembangunan infastruktur jalan baik jalan baru, program pemeliharaan jalan maupun program peningkatan jalan.

Mengingat pentingnya jalan sebagai pendukung aktifitas ekonomi dalam kehidupan masyarakat, maka mutu dari jalan harus senantiasa diperhatikan dan dijaga. Namun dalam praktiknya masih ditemukan hasil pekerjaan jalan yang tidak sesuai dengan yang disyaratkan, hal ini mengakibatkan jalan mudah rusak dan mengurangi umur rencana jalan.

Hal tersebut didukung oleh hasil penelitian Mulyono (2008) $)^{[5]}$ yang menyatakan bahwa faktor dominan penyebab kerusakan jalan terdiri dari faktor mutu konstruksi perkerasan sebesar 44,2\%, faktor air drainase permukaan jalan sebesar $40,2 \%$ dan faktor repetisi beban kendaraan sebesar 15,6\%.

Oleh karena itu dalam rangka menjaga mutu dari infrastruktur jalan tersebut tidak terlepas dari banyaknya kendala yang akan muncul dan seringkali tidak dapat diprediksi. Kejadian-kejadian ketidakpastian seperti itu dapat kita identifikasi menjadi risiko yang akan muncul.

Dalam penelitian ini akan membahas bagaimana identifikasi peristiwa risiko dominan yang berpengaruh terhadap kinerja mutu proyek menggunakan metode Analytical Hierarchy Process (AHP) yang selanjutnya faktor risiko dominan tersebut akan dicari seberapa besar pengaruh signifikannya terhadap peningkatan/penurunan kineja mutu proyek pemeliharaan jalan menggunakan model Regresi Linear Berganda. 


\section{TINJAUAN PUSTAKA}

\subsection{Proyek Perkerasan Jalan}

Dalam pekerjaan pembangunan istilah proyek sering kita dengar. Utamanya bila kita sering berkecimpung dalam dunia kontraktor/pelaksana pembangunan. Secara umum proyek merupakan sebuah kegiatan pekerjaan yang dilaksanakan atas dasar permintaan dari seorang pemilik pekerjaan yang ingin mencapai suatu tujuan tertentu dan dilaksanakan oleh pelaksana pekerjaan sesuai dengan keinginan pemilik/owner dan spesifikasi yang ada. Dalam dunia pembangunan ada beberapa macam proyek yang dilaksanakan oleh kontraktor, diantaranya adalah proyek gedung (perumahan, perkantoran, pabrik, bangunan umum), irigasi (saluran, dam), prasarana transportasi (jalan, jembatan) serta bangunan fisik lainnya.

\subsection{Tahapan Pelaksanaan Proyek Jalan Perkerasan Lentur}

Menurut Asiyanto (2008) : Tahapan pelaksanaan pekerjaaan dengan perkerasan aspal perkerasan lentur (flexible pavement) ini meliputi: pekerjaan persiapan, pekerjaan pengukuran, pekerjaan subgrade, pekerjaan subbase, pekerjaan trial hot mix dan percobaan pemadatan hot mix, pekerjaan base course (asphalt treated base), pekerjaan sambungan hot mix, pekerjaan surface course, pekerjaan tes sampel dan pekerjaan bahu jalan (shoulder). [1]

\subsection{Pekerjaan Perkerasan Lentur Lapis Permukaan \\ Pekerjaan lapis permukaan (surface} course) menggunakan campuran aspal panas (hot mix) sebelumnya waktu penghamparannya tidak boleh dilakukan waktu hujan, karena akan mengurangi mutu dari aspal beton yang dihasilkan serta harus disediakan alat komunikasi (HT, radio, handphone, dll) untuk berkomunikasi antara AMP dan tempat phenghamparan hot mix. [1]

\subsection{Pemeliharaan Perkerasaan Lentur Jalan}

Pemeliharaan perkerasan merupakan pekerjaan yang penting dalam perkerasan lentur jalan. Hardiyatmo (2007:153) [4] menyatakan bahwa perkerasan secara terus menerus akan mengalami tegangan-tegangan akibat beban lalu lintas yang dapat mengakibatkan kerusakan minor pada perkerasan. Selain itu, temperatur, kelembapan, dan gerakan tanah dasar dapat pula menyebabkan kerusakan perkerasan. Dalam pekerjaan perbaikan suatu perkerasan, maka dikenal isntilah-istilah pemeliharaan dan rehabilitasi.

\subsection{Konsep Kualitas}

Definisi kualitas (mutu) menurut sukirman (2003) [7] yaitu kesesuaian dengan persyaratan dan cocok untuk digunakan. Sedangkan dalam kerangka ISO 9000 didefinisikan sebagai ciri dan karakter menyeluruh dari suatu produk atau jasa yang mempengaruhi kemampuan produk tersebut untuk memuaskan kebutuhan tertentu.

\subsection{Analisis Statistik}

Pengelolaan data dianlisis secara statistik dengan menggunakan bantuan program Statistical Program for Social Science (IBM SPPS 21) yang merupakan program pengolah data statistik. Analisis statistik data tersebut meliputi:

1. Uji Mann Whitney U Test

2. Uji Kruskall Wallis $H$

3. Uji Validitas dan Reabilitas Data

4. Analisi Regresi Linear Berganda

\subsection{Analisis Hierarki Proses (AHP)}

AHP merupakan suatu metode pendukung keputusan yang dikembangkan oleh seorang professor matematika University of Pittsburgh kelahiran Irak, Thomas L. Saaty (2008) [6]. AHP merupakan metode untuk membuat urutan alternatif keputusan dan pemilihan alternatif terbaik pada saat pengambil keputusan dengan beberapa tujuan atau kriteria untuk mengambil keputusan.

Langkah pertama dalam melakukan analisis ini adalah membuat matriks berpasangan untuk frekuensi risiko dan dampak risiko yang diperoleh berdasarkan penilaian setiap kriterianya ditentukan sesuai dengan Tabel 1 yaitu tabel skala penilaian AHP. Untuk melakukan pembobotan dan penilaian risiko menggunakan metode Analisis Hirarki Proses (AHP), dimulai dengan membuat matriks berpasangan untuk dampak dan frekuensi risiko, menentukan pembobotan matriks, melakukan perhitungan konsistensi matriks, menentukan nilai faktor risiko, dan yang 
berikutnya adalah menentukan Rangking dan Level Risiko.

Tabel 1. Skala penilaian AHP

\begin{tabular}{c|l|l}
\hline $\begin{array}{c}\text { Tingkat } \\
\text { Kepentingan }\end{array}$ & \multicolumn{1}{|c}{ Definisi } & \multicolumn{1}{c}{ Penjelasan } \\
\hline 1 & $\begin{array}{l}\text { Sama pentingnya } \\
\text { dibanding yang } \\
\text { lain }\end{array}$ & $\begin{array}{l}\text { Kedua elemen } \\
\text { menyumbang } \\
\text { sama besar pada } \\
\text { sifat tersebut. }\end{array}$ \\
\hline 3 & $\begin{array}{l}\text { Moderat } \\
\text { pentingnya } \\
\text { dibanding yang } \\
\text { lain }\end{array}$ & $\begin{array}{l}\text { Pengalaman } \\
\text { menyatakan } \\
\text { sedikit berpihak } \\
\text { pada satu elemen }\end{array}$ \\
\hline 5 & $\begin{array}{l}\text { Kuat pentingnya } \\
\text { dibanding yang } \\
\text { lain }\end{array}$ & $\begin{array}{l}\text { Pengalaman } \\
\text { menunjukan } \\
\text { secara kuat } \\
\text { memihak pada } \\
\text { satu elemen. }\end{array}$ \\
\hline 7 & $\begin{array}{l}\text { Sangat kuat } \\
\text { pentingnya } \\
\text { dibanding yang } \\
\text { lain }\end{array}$ & $\begin{array}{l}\text { Pengalaman } \\
\text { menunjukan } \\
\text { secara kuat } \\
\text { disukai dan } \\
\text { dominan dalam } \\
\text { praktek }\end{array}$ \\
\hline 9 & $\begin{array}{l}\text { Ekstrim } \\
\text { pentingnya } \\
\text { dibanding yang } \\
\text { lain }\end{array}$ & $\begin{array}{l}\text { menunjukan satu } \\
\text { elemen sangat } \\
\text { jelas lebih } \\
\text { penting }\end{array}$ \\
\hline
\end{tabular}

Sumber: Thomas L. Saaty (2008)

Berdasarkan hasil kajian peristiwaperistiwa risiko pemeliharan jalan yang dilakukan penilaian menggunakan skala penilaian AHP meliputi:

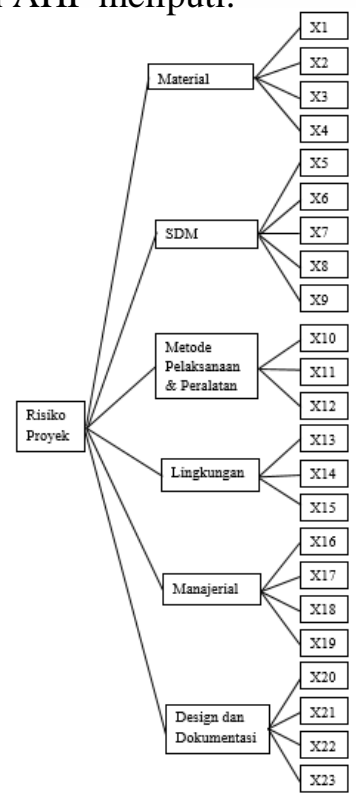

Gambar 1. Skema Hirarki Risiko Proyek Pemeliharaan Jalan

\subsection{Variabel Penelitian}

Dimana Variabel X1 hingga variabel X23 pada gambar.2 penelitian ini didapat dari penelitian terdahulu oleh Fandopa (2012) [3], dan Zulianto (2015) $)^{[8]}$ serta beberapa dari dokumentasi proyek. Variabel bebas dari penelitian ini ditinjau beberapa aspek meliputi:

\section{- Aspek Material}

X1 Material yang dipakai tidak sesuai spesifikasi.

X2 Jumlah material yang dibutuhkan kurang

X3 Kedatangan material terlambat

X4 Temperatur Kedatanagan Material Aspal Hot Mix kurang dari yang Disyaratkan

- Aspek Sumber Daya Manusia

X5 Kemampuan Tenaga Pelaksana Kurang

X6 Tingkat keahlian tenaga kerja tidak cukup

X7 Kualitas tim engineering proyek kurang baik

X8 Kompetensi personil tidak sesuai dengan tugasnya

X9 Salah dalam mengambil keputusan

\section{- Metode Pelaksanaan dan Peralatan}

X10 Metode pelaksanaan tidak tepat

X11 Jenis peralatan yang digunakan tidak tepat

X12 Buruknya penataan site layout

\section{- Lingkungan}

X13 Cuaca kurang baik

X14 Kondisi lapangan sulit

X15 Kerusakan oleh pihak ketiga

- Manajerial

X16 Distribusi data/ informasi kurang baik

X17 Komunikasi antar pihak kurang baik

X18 Kurangnya teamwork

X19 Kurangnya komitmen dalam hal quality assurance dan quality control

\section{- Desain dan Dokumentasi}

X20 Kesalahan desain

X21 Spesifikasi sulit dimengerti

X22 Adanya perubahan desain dan lingkup pekerjaan

X23 Pengedalian dokumen di lapangan tidak baik 


\section{METODE PENELITIAN}

Penelitian ini dilaksanakan pada proyek jalan yang ada di Kabupaten Malang pada pekerjaan aspal hotmix dengan lingkup permasalahan mengenai analisis tingkat risiko proyek yang berpengaruh terhadap kinerja mutu proyek kemudian ditentukan cara penanganan yang tepat terhadap peristiwaperistiwa risiko tersebut.

\subsection{Diagram Alir Penelitian}

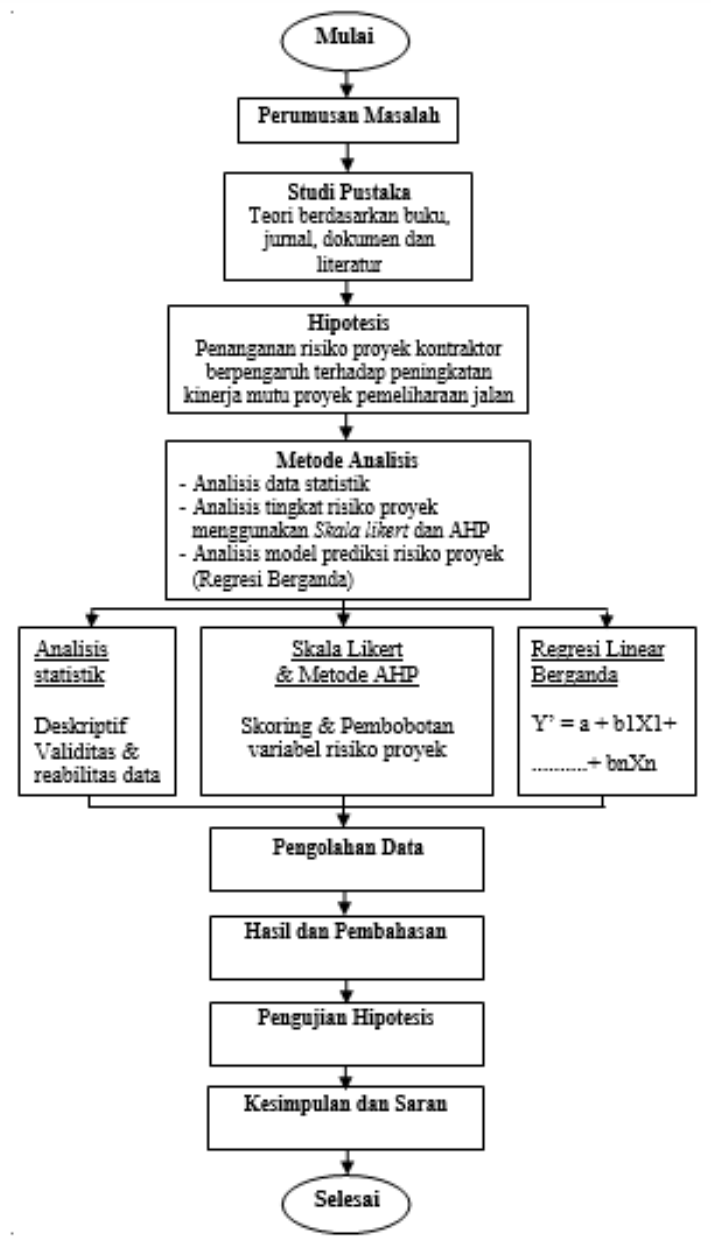

Gambar 2. Diagram alir penelitian

\subsection{Pengumpulan Data}

Data yang digunakan adalah data primer dan data sekunder. Data primer diperoleh dari pembagian kuisioner frekuesi dan dampak risiko kepada 50 orang responden yang terdiri dari konsultan pengawas, dinas PU Binamarga, dan kontraktor yang terlibat dalam proyek pelaksanaan pembangunan jalan. Sementara data sekunder diperoleh dari survei lapangan dan data literatur yang berhubungan dengan penelitian.

\subsection{Pengelompokan Responden}

Pengelompokan responden dalam penilitian ini adalah berjumlah 50 responden yang dibagi dalam karakteristik responden pada Tabel 2.

Tabel 2. Karakteristik responden

\begin{tabular}{lc}
\hline \multicolumn{1}{c}{ Karakteristik Responden } & Jumlah \\
\hline Pendidikan Responden: & 36 \\
$\circ \quad$ Sarjana (S2 dan S1) & \\
$\circ \quad$ Non Sarjana (D3/D4 dan & 14 \\
$\quad$ SLTA) & \\
\hline Pengalaman Bekerja Responden: & 39 \\
$\circ \quad<15$ th & 11 \\
$\circ \quad 15$ - 30 th & 15 \\
\hline Jabatan Responden: & 10 \\
$\circ \quad$ Konsultan Pengawas & 25 \\
\hline Dinas PU Bina Marga & \\
\hline$\quad$ Kontraktor &
\end{tabular}

\subsection{Analisis Data Responden}

Analisis data responden dilakukan untuk menilai instrumen penelitian dengan program IBM SPSS 21. Analisis yang digunakan adalah analisis statistic nonparametric Mann Whitney $U$ Test dan Kruskall Wallis $H$ untuk menguji perbedaan persepsi responden ditinjau dari latar belakang pendidikan dan pengalaman bekerja responden. Selanjutnya dilakukan uj validitas dan uji reabilitas instrumen penelitian. Analisis statitistik deskriptif digunakan untuk memberikan gambaran sekilas mengenai faktor risiko dominan pada proyek dilihat dari nilai mean tertinggi.

\section{HASIL DAN PEMBAHASAN \\ 4.1 Analisis Data Responden dan Data Kuesioner}

Pada tahapan ini dilakukan uji perbedaan persepsi jawaban antara latar belakang pendidikan responden dan pengalaman bekerja responden. Berdasarkan jumlah responden pada Tabel 2 dan jawaban kuesioner yang berjumlah 23 varibel dilakukan Uji Mann-Whitney deengan hipotesis sebagai berikut:

$\mathrm{Ho}=$ Tidak ada perbedaan persepsi responden yang memiliki pendidikan Sarjana dan Non Sarjana.

$\mathrm{Hi}=$ Terdapat perbedaan persepsi responden yang memiliki pendidikan terakhir Sarjana dan Non Sarjana. 
Pedoman untuk pengambilan keputusan adalah sebagai berikut:

- Jika probabilitas (Asymp.sig.2tailed) > 0,05, maka Ho diterima.

- Jika probabilitas (Asymp.sig.2tailed) < 0,05, maka Ho ditolak.

Berdasarkan hasil uji Mann Whitney, nilai probabilitas variabel yang diperoleh seluruhnya lebih besar dari 0,05. Maka Ho diterima sehingga dapat disimpulkan bahwa tidak ada perbedaan persepsi jawaban respoden yang memiliki latar belakang pendidikan yang berbeda.

Berikutnya adalah uji perbedaan persespsi jawaban responden berdasarkan pengalaman responden. Pada tabel 2 pengalaman responden terdiri dari pengalan bekerja dibawah 15 tahun dan diatas 15 tahun. Pedoman untuk pengambilan keputusan adalah sebagai berikut:

- Jika probabilitas (Asymp.sig.2tailed) > 0,05 , maka Ho diterima.

- Jika probabilitas (Asymp.sig.2tailed) < 0,05, maka Ho ditolak.

Berdasarkan hasil uji Kruskal Wallis, nilai probabilitas variabel yang diperoleh seluruhnya lebih besar dari 0,05 kecuali pada X15. Pada variabel X15 nilai Asymp. Sig. (2-tailed) adalah 0,022 yang berarti bahwa Ho ditolak dan H1 diterima, hal ini menunjukkan bahwa pada variabel X15 terdapat perbedaan persepsi responden yang berbeda pada tingkat pengalaman kerja. Hal ini dikarenakan responden yang memiliki pengalaman 15 tahun keatas lebih banyak mengetahui mengenai pelaksanaan dilapangan dibandingkan dengan responden yang memiliki pengalaman dibawah 15 tahun.

Sebelum data dapat dianalisa lebih lanjut, dilakukan pengujian terhadap validitas data yang diperoleh dari responden. Kriteria pengujian validitas jika $r$ hitung $>r$ tabel maka pertanyaan dinyatakan valid dan sebaliknya jika $r$ hitung $<~ r$ tabel maka dinyatakan tidak valid. Dengan menggunakan tabel distribusi (tabel r) untuk $\alpha=0,05$ dan jumlah responden sebanyak 50, sehingga didapat $r$ tabel $=0,279$. Setelah dilakukan pengujian terdapat 4 variabel yang tidak valid yaitu X19, X20, X22, X23. Variabel yang tidak valid ini tidak akan digunakan untuk pengujia berikutnya.

Instrumen penelitian harus reliabel sehingga dilakukan uji reliabilitas menggunakan metode CronbachAlpha. Dengan pedoman sebagai berikut: Nilai CronbachAlpha $\leq 0,6$ menunjukkan bahwa kuisioner penelitian tidak reliabel. Nilai CronbachAlpha $\geq 0,6$ menunjukkan bahwa kuisioner penelitian reliabel. Berdasarkan hasil uji reliabilitas data penelitian mengunakan metode Cronbach Alpha diperoleh nilai 0,918 sehingga instrumen penelitian dikatakan reliabel dan dapat digunakan.

\subsection{Analisis Faktor Risiko dengan Statistik Deskriptif}

Analisis statistik deskriptif digunakan untuk menentukan variabel faktor risiko yang memiliki nilai mean tertinggi. Dari hasil analisis tersebut diperoleh faktor risiko X15 yaitu terjadinya kerusakan oleh pihak ketiga yang memperoleh nilai mean tertinggi dengan nilai mean sebesar 3,66.

\subsection{Analisis Tingkat Risiko dengan metode AHP}

Langkah awal dalam analisis AHP adalah dengan membuat matriks berpasangan untuk frekuensi dan dampak risiko. Berikut ini adalah hasil matriks berpasangan untuk frekuensi dan dampak risiko:

Tabel 3. Matriks berpasangan frekuensi dan dampak risiko

\begin{tabular}{c|c|c|c|c|c}
\hline & $\begin{array}{c}\text { Selalu } \\
\text { terjadi }\end{array}$ & $\begin{array}{c}\text { Sering } \\
\text { terjadi }\end{array}$ & Terjadi & $\begin{array}{c}\text { Kadang } \\
\text { terjadi }\end{array}$ & $\begin{array}{c}\text { Jarang } \\
\text { terjadi }\end{array}$ \\
\hline $\begin{array}{c}\text { Selalu } \\
\text { terjadi }\end{array}$ & 1 & 3 & 5 & 7 & 9 \\
\hline $\begin{array}{c}\text { Sering } \\
\text { terjadi }\end{array}$ & 0,333 & 1 & 3 & 5 & 7 \\
\hline Terjadi & 0,200 & 0,333 & 1 & 3 & 5 \\
\hline $\begin{array}{c}\text { Kadang } \\
\text { terjadi }\end{array}$ & 0,143 & 0,200 & 0,333 & 1 & 3 \\
\hline $\begin{array}{c}\text { Jarang } \\
\text { terjadi }\end{array}$ & 0,111 & 0,143 & 0,200 & 0,333 & 1 \\
\hline \begin{tabular}{c} 
Jumlah \\
\hline \hline
\end{tabular} & 1,787 & 4,676 & 9,533 & 16,333 & 25 \\
\hline $\begin{array}{c}\text { Selalu } \\
\text { berdampak }\end{array}$ & 1 & 3 & 5 & 7 & 9 \\
\hline $\begin{array}{c}\text { Sering } \\
\text { berdampak }\end{array}$ & 0,333 & 1 & 3 & 5 & 7 \\
\hline $\begin{array}{c}\text { Terjadi } \\
\text { berdampak }\end{array}$ & 0,200 & 0,333 & 1 & 3 & 5 \\
\hline $\begin{array}{c}\text { Kadang } \\
\text { berdampak }\end{array}$ & 0,143 & 0,200 & 0,333 & 1 & 3 \\
\hline $\begin{array}{c}\text { Tidak } \\
\text { berdampak }\end{array}$ & 0,111 & 0,143 & 0,200 & 0,333 & 1 \\
\hline Jumlah & 1,787 & 4,676 & 9,533 & 16,333 & 25 \\
\hline \\
berdampak & berdampak & Berdampak & berdampak & $\begin{array}{c}\text { Tidak } \\
\text { berdampak }\end{array}$ \\
\hline
\end{tabular}

Selanjutnya adalah mencari bobot frekuensi dan dampak risiko dengan cara mencari nilai prioritas tiap elemen matriks. 
Tabel 4. Nilai prioritas elemen matriks

\begin{tabular}{c|c|c|c|c|c|c|c|c}
\hline & $\begin{array}{c}\text { Selalu } \\
\text { terjadi }\end{array}$ & $\begin{array}{c}\text { Sering } \\
\text { terjadi }\end{array}$ & Terjadi & $\begin{array}{c}\text { Kadang } \\
\text { terjadi }\end{array}$ & $\begin{array}{c}\text { Jarang } \\
\text { terjadi }\end{array}$ & $\begin{array}{c}\text { Jumlah } \\
\text { bobot }\end{array}$ & $\begin{array}{c}\text { Priority } \\
\text { Vector }\end{array}$ & Persentase \\
\hline $\begin{array}{c}\text { Selalu } \\
\text { terjadi }\end{array}$ & 0,56 & 0,64 & 0,52 & 0,43 & 0,36 & 2,51 & $\mathbf{0 , 5 0}$ & $\mathbf{1 0 0 , 0 0 \%}$ \\
\hline $\begin{array}{c}\text { Sering } \\
\text { terjadi }\end{array}$ & 0,19 & 0,21 & 0,31 & 0,31 & 0,28 & 1,30 & $\mathbf{0 , 2 6}$ & $\mathbf{5 1 , 7 5 \%}$ \\
\hline Terjadi & 0,11 & 0,07 & 0,10 & 0,18 & 0,20 & 0,67 & $\mathbf{0 , 1 3}$ & $\mathbf{2 6 , 7 2 \%}$ \\
\hline $\begin{array}{c}\text { Kadang } \\
\text { terjadi }\end{array}$ & 0,08 & 0,04 & 0,03 & 0,06 & 0,12 & 0,34 & $\mathbf{0 , 0 7}$ & $\mathbf{1 3 , 4 8 \%}$ \\
\hline $\begin{array}{c}\text { Jarang } \\
\text { terjadi }\end{array}$ & 0,06 & 0,03 & 0,02 & 0,02 & 0,04 & 0,17 & $\mathbf{0 , 0 3}$ & $\mathbf{6 , 9 3} \%$ \\
\hline Jumlah & 1,00 & 1,00 & 1,00 & 1,00 & 1,00 & 5,00 & & \\
\hline
\end{tabular}

Sebagai contoh Nilai 0,56 pada Tabel 4 diatas diperoleh dari nilai pada tabel matriks berpasangan frekuensi risiko untuk kriteria selalu terjadi dan selalu terjadi adalah 1 , nilai tersebut dibagi dengan jumlah kolom yaitu 1,787 sehingga diperoleh hasil 0,56. Lanjutkan perhitungan untuk tiap kolom dengan cara yang sama. Setelah memperoleh bobot tiap elemen, hitung nilai prioritasnya dengan cara membagi jumlah bobot elemen tiap baris dengan jumlah elemen yaitu 5 hingga diperoleh nilai pada priority vektor (tabel 4) 2,51/5 =0,50. Lakukan hal yang sama pada baris berikutnya sehingga diperoleh pembobotan matriks sebagai berikut: dalam hal ini nilai pembobotan matriks untuk frekuensi dan dampak risiko adalah sama.

Tabel 5. Pembobotan matriks frekuensi dan dampak risiko

\begin{tabular}{c|c|c|c|c|c}
\hline & $\begin{array}{c}\text { Selalu } \\
\text { berdampak }\end{array}$ & $\begin{array}{c}\text { Sering } \\
\text { berdampak }\end{array}$ & berdampak & $\begin{array}{c}\text { Kadang } \\
\text { berdampak }\end{array}$ & $\begin{array}{c}\text { Jarang } \\
\text { berdampak }\end{array}$ \\
\hline Bobot & 1 & 0,518 & 0,267 & 0,135 & 0,069 \\
\hline
\end{tabular}

Banyaknya elemen dalam matriks (n) adalah 5, dan perhitungan konsistensi matriks berdasarkan vektor eigen diperoleh jumlah hasil kali matrik/vektor eigen adalah 26,21. Maka $\lambda$ maks $=26,21 / 5$, sehingga diperoleh $\lambda$ maks $=5,24$; nilai tersebut mendekati jumlah elemen (n) yaitu 5, sehingga diperoleh nilai sisa vektor eigen $=0,24(5,24-5)$ dan mendekati angka nol (0), Maka dapat dikatakan hasil perhitungan uji matriks tersebut adalah KONSISTEN.

Untuk melakukan Uji Konsistensi Hirarki terlebih dahulu harus diketahui indeks konsistensi matriks dan berapa rasio konsistensinya, sehingga langkah awal yang harus dilakukan adalah menghitung indeks konsistensi menggunakan rumus sebagai berikut: $C I=(\lambda$ maks $-n) /(n-1) \ldots \ldots$. Saaty $(2008)$

Dimana : $\mathrm{CI}=$ Consistency Index $\lambda$ maks $=$ Nilai Vektor Eigen terbesar dari matriks berordo $n$

$\mathrm{n}=$ Banyaknya elemen matriks

Sehingga diperoleh nilai

$\mathrm{CI}=(5,24-1) /(5-1)$

$=0,06$

Dan selanjutnya menghitung Rasio

Konsistensinya menggunakan rumus:

$\mathrm{CR}=\mathrm{CI} / \mathrm{RI}$....... Saaty (2008)

Dimana CR = Consistency Ratio

$\mathrm{CI}=$ Consistency Index

RI = Random Consistency

Index,

dimana RI ini dapat diperoleh melalui Tabel

Random Consistency Index sebagai berikut:

Tabel 6. Nilai random konsistensi index

\begin{tabular}{ccccccccccc}
\hline $\mathrm{n}$ & 1 & 2 & 3 & 4 & 5 & 6 & 7 & 8 & 9 & 10 \\
\hline $\mathrm{RI}$ & 0 & 0 & 0,58 & 0,9 & 1,12 & 1,24 & 1,32 & 1,41 & 1,45 & 1,49
\end{tabular}

Sumber: Fandopa (2012; pg.106)

Sehingga diperoleh nilai CR

$=0,06 / 1,12$

$=0,05=5 \%$

Dari perhitungan diatas nilai $\mathrm{CR}$ yang didapat adalah $5 \%$ dan lebih kecil dari $10 \%$, maka dapat diambil keputusan bahwa hirarki konsisten dan tingkat akurasi tinggi.

Langkah berikutnya adalah menentukan rata-rata nilai lokal untuk frekuensi risiko dengan cara mengalikan bobot risiko dengan skor masing-masing variabel risiko berdasarkan jawaban kuesioner. Rata-rata frekuensi dan dampak risiko digunakan untuk mencari nilai faktor risiko menggunakan rumus:

$\mathrm{FR}=(\mathrm{L}+\mathrm{I})-(\mathrm{L} \times \mathrm{I}) \ldots \ldots . . .($ Asmarantaka 2014)

Dimana:

FR =Faktor Risiko dengan skala 0-1

$\mathrm{L} \quad=$ Besaran frekuensi terjadinya risiko

I $=$ Besaran dampak risiko

\subsection{Rangking dan Level Risiko}

SNI Risk Management Guidelines th. 2006 dalam Asmarantaka (2014) ${ }^{[2]}$ menyebutkan bahwa kategori risiko tinggi jika nilai Faktor Risiko $(\mathrm{FR})>0,7$, kategori risiko sedang jika nilai $\mathrm{FR}=0,4-0,7$ dan kategori risiko rendah jika nilai $F R<0,4$. Sehingga diperoleh rekapan rangking dan level risiko pada Tabel 8. 
Tabel 7. Faktor risiko

\begin{tabular}{c|r|r|c}
\hline Variabel & $\begin{array}{c}\text { Rata-rata } \\
\text { nilai lokal } \\
\text { Frekuensi } \\
\text { (L) }\end{array}$ & $\begin{array}{c}\text { Rata- } \\
\text { rata nilai } \\
\text { lokal } \\
\text { Dampak } \\
\text { (I) }\end{array}$ & $\begin{array}{c}\text { Faktor } \\
\text { Risiko }\end{array}$ \\
\hline X1 & 0,17 & 0,50 & 0,584 \\
\hline X2 & 0,20 & 0,33 & 0,466 \\
\hline X3 & 0,28 & 0,26 & 0,466 \\
\hline X4 & 0,15 & 0,37 & 0,470 \\
\hline X5 & 0,12 & 0,26 & 0,351 \\
\hline X6 & 0,14 & 0,34 & 0,432 \\
\hline X7 & 0,13 & 0,34 & 0,422 \\
\hline X8 & 0,14 & 0,34 & 0,430 \\
\hline X9 & 0,14 & 0,43 & 0,509 \\
\hline X10 & 0,15 & 0,46 & 0,536 \\
\hline X11 & 0,14 & 0,38 & 0,466 \\
\hline X12 & 0,15 & 0,35 & 0,450 \\
\hline X13 & 0,21 & 0,40 & 0,527 \\
\hline X14 & 0,19 & 0,26 & 0,402 \\
\hline X15 & 0,39 & 0,51 & 0,701 \\
\hline X16 & 0,18 & 0,24 & 0,374 \\
\hline X17 & 0,15 & 0,23 & 0,346 \\
\hline X18 & 0,12 & 0,26 & 0,355 \\
\hline X21 & 0,13 & 0,37 & 0,449 \\
\hline
\end{tabular}

Tabel 8. Rangking dan level risiko

\begin{tabular}{c|c|c|c}
\hline Variabel & FR & $\begin{array}{c}\text { Risk } \\
\text { Rangking }\end{array}$ & $\begin{array}{c}\text { Risk } \\
\text { Level }\end{array}$ \\
\hline $\mathrm{X} 1$ & 0,584 & 2,0 & Sedang \\
\hline $\mathrm{X} 2$ & 0,466 & 10,0 & Sedang \\
\hline $\mathrm{X} 3$ & 0,466 & 9,0 & Sedang \\
\hline $\mathrm{X} 4$ & 0,470 & 7,0 & Sedang \\
\hline $\mathrm{X} 5$ & 0,351 & 20,0 & Rendah \\
\hline $\mathrm{X} 6$ & 0,432 & 13,0 & Sedang \\
\hline $\mathrm{X} 7$ & 0,422 & 15,0 & Sedang \\
\hline $\mathrm{X} 8$ & 0,430 & 14,0 & Sedang \\
\hline $\mathrm{X} 9$ & 0,509 & 6,0 & Sedang \\
\hline $\mathrm{X} 10$ & 0,536 & 3,0 & Sedang \\
\hline $\mathrm{X} 11$ & 0,466 & 8,0 & Sedang \\
\hline $\mathrm{X} 12$ & 0,450 & 11,0 & Sedang \\
\hline $\mathrm{X} 13$ & 0,527 & 4,0 & Sedang \\
\hline $\mathrm{X} 14$ & 0,402 & 16,0 & Sedang \\
\hline $\mathrm{X} 15$ & 0,701 & 1,0 & Tinggi \\
\hline $\mathrm{X} 16$ & 0,374 & 18,0 & Rendah \\
\hline $\mathrm{X} 17$ & 0,346 & 21,0 & Rendah \\
\hline $\mathrm{X} 18$ & 0,355 & 19,0 & Rendah \\
\hline $\mathrm{X} 21$ & 0,449 & 12,0 & Sedang \\
\hline & & &
\end{tabular}

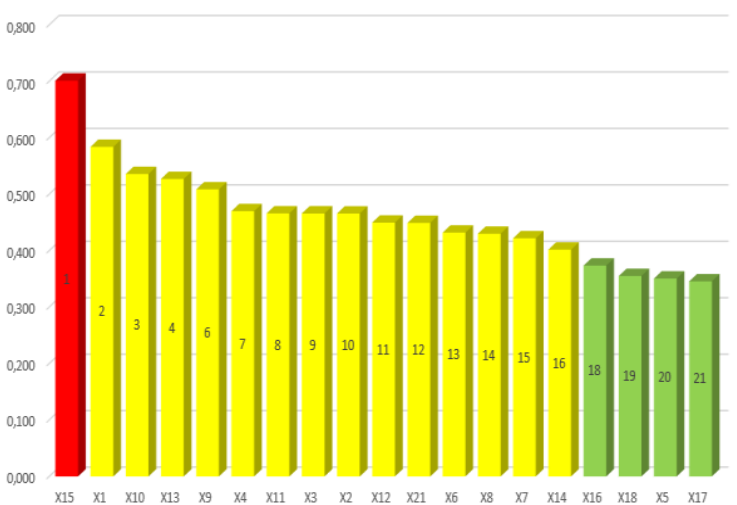

Gambar 2. Grafik rangking dan level risiko

Dari Gambar 2 lebih mudah dipahami bahwa tingkat risiko tertinggi berwarna merah ada pada X15 berjumlah 1 variabel, tingkat risiko sedang berwarna kuning ada pada $X 1$, $\mathrm{X} 10, \mathrm{X} 13, \mathrm{X} 9, \mathrm{X} 4, \mathrm{X} 11, \mathrm{X} 3, \mathrm{X} 2, \mathrm{X} 12, \mathrm{X} 21$, $\mathrm{X} 6, \mathrm{X} 8, \mathrm{X} 7$, dan $\mathrm{X} 14$ berjumlah 15 variabel. Tingkat risiko rendah berwarna hijau, ada pada X16, X18, X5, dan X17 berjumlah 4 variabel. Sehingga didapatkan 15 variabel yang didapatkan sebagai acuan untuk mencari penanganan/solusi terhadap peristiwa-peristiwa tersebut.

\subsection{Hasil Uji Analisis Regresi Linier Berganda}

Dalam penelitian ini Uji Regresi Linear berganda bertujuan untuk mencari pengaruh signifikan peristiwa risiko terhadap kinerja mutu proyek serta seberapa besar pengaruhnya terhadap peningkatan/penurunan kinerja mutu proyek yang ditunjukan melalui nilai positif/negatif pada koefisien model regresi yang terbentuk. 15 peristiwa risiko dengan kategori tinggi dan sedang dari metode AHP kemudian diproses untuk memperoleh nilai koefisien dari rumus regresi linear berganda dengan bantuan software IBM SPSS 21 melalui input data kemudian perintah Analyze Regression - Linear - Backward Elimanation dimana metode backward ini bekerja dengan mengeluarkan satu per satu variabel prediktor yang tidak signifikan dan dilakukan terus menerus sampai tidak ada variabel prediktor yang tidak signifikan. sehingga menghasilkan output pengaruh signifikan variabel $X$ (peristiwa risiko) terhadap variabel Y (kinerja mutu) sebagai berikut:

Nilai $\mathrm{F}$ tabel untuk $\mathrm{n}=50$ dan $\mathrm{k}=9$ adalah $\mathrm{F}(\mathrm{k} ; \mathrm{n}-\mathrm{k})$ yaitu $\mathrm{F}(9 ; 49)$ angka tersebut 
selanjutnya dicari pada tabel distribusi $\mathrm{F}$ pada probabilitas 0,05 sehingga diperoleh nilai $\mathrm{F}$ tabel $=2,12$.

Dari perhitungan analisis regresi menggunakan metode Backward Elimnation diperoleh nilai Fpartial pada X2, X9 dan X3 adalah 2,712 lebih besar (>) Ftabel 2,12 sehingga dapat diambil keputusan bahwa X2, X9 dan X3 digunakan/dipilih sebagai variabel yang signifikan untuk dilakukan uji regresi linear berganda. Hasil uji regresi linear berganda diperoleh besarnya konstanta (a) = 4,090 dan nilai koefisien regresi $(\mathrm{b} 2)=-0,118$, $(\mathrm{b} 3)=-0,074$, dan $(\mathrm{b} 9)=-0,087$ sehingga diperoleh model persamaan regresi linier berganda sebagai berikut :

$\mathrm{Y}=4,090-0,118 \mathrm{X}_{2}-0,074 \mathrm{X}_{3}-0,087 \mathrm{X}_{9}$

Dimana $\mathrm{Y}=$ Kinerja Mutu

$\mathrm{X} 2$ = Jumlah material yang

dibutuhkan kurang

$\mathrm{X} 3$ = Kedatangan material terlambat

X9 = Salah dalam mengambil

keputusan

intepretasi dari model regresi tersebut adalah:

- Konstanta sebesar 4,090; artinya jika X2, $X 3$, dan $X 9$ nilainya adalah 0 , maka kinerja mutu (Y) nilainya adalah 4,090.

- Koefisien regresi variabel X2 (Jumlah material kurang) sebesar - 0,118 ; artinya jika variabel independen lain nilainya tetap dan X2 mengalami kenaikan 1\%, maka kinerja mutu akan mengalami penurunan sebesar 0,118 . Koefisien bernilai negatif artinya terjadi hubungan negatif antara X2 dengan kinerja mutu, semakin meningkat peristiwa risiko pada X2 maka semakin menurunkan kinerja mutu.

- Koefisien regresi variabel X3 (kedatangan material terlambat) sebesar -0,074; artinya jika variabel independen lain nilainya tetap dan X3 mengalami kenaikan 1\%, maka kinerja mutu akan mengalami penurunan sebesar 0,074. Koefisien bernilai negatif artinya terjadi hubungan negatif antara X3 dengan kinerja mutu, semakin meningkat peristiwa risiko pada X3 maka semakin menurunkan kinerja mutu.

- Koefisien regresi variabel X9 (salah dalam mengambil keputusan) sebesar -0,087; artinya jika variabel independen lain nilainya tetap dan $\mathrm{X} 9$ mengalami kenaikan $1 \%$, maka kinerja mutu akan mengalami penurunan sebesar 0,087. Koefisien bernilai negatif artinya terjadi hubungan negatif antara X9 dengan kinerja mutu, semakin meningkat peristiwa risiko pada X9 maka semakin menurunkan kinerja mutu.

Pada pengujian pengaruh signifikan menggunakan metode backward elimination ini variabel X15 yang memiliki kategori risiko paling tinggi pada metode AHP pada tahap ini tereliminasi karena nilai F-partial lebih kecil dari nilai F-tabel. Hal ini didukung dengan hasil uji Mann-Whitney yang terdapat perbedaan persepsi jawaban pada X15 pada tingkat pengalaman responden yang berbeda.

Berdasarkan intepretasi dari model regresi diperoleh faktor risiko dari aspek Material (X2,X3) dan Sumber Daya Manusia (X9) berpengaruh signifikan terhadap penurunan kinerja mutu proyek sebesar koefisien pada masing-masing variabel risiko proyek.

\section{KESIMPULAN DAN SARAN \\ 5.1 Kesimpulan}

Peristiwa-peristiwa risiko yang masuk dalam kategori tinggi dan sedang pada pelaksanaan proyek pelaksanaan pemeliharaan jalan aspal hotmix di Kabupaten Malang menggunakan metode AHP meliputi:

X15 Kerusakan oleh pihak ketiga

X1 Material yang dipakai tidak sesuai spesifikasi.

X10 Metode pelaksanaan tidak tepat

X13 Cuaca kurang baik

X9 Salah dalam mengambil

keputusan

X4 Temperatur Kedatangan Material Aspal Hot Mix kurang dari yang disyaratkan

X11 Jenis peralatan yang digunakan tidak tepat

X3 Kedatangan material terlambat

X2 Jumlah material yang dibutuhkan kurang

X12 Buruknya penataan site layout

X21 Spesifikasi sulit dimengerti

X6 Tingkat keahlian tenaga kerja tidak cukup

X8 Kompetensi personil tidak sesuai dengan tugasnya

X7 Kualitas tim engineering proyek kurang baik

X14 Kondisi lapangan sulit

Dari pengujian regresi linear berganda risiko-risiko proyek yang memiliki pengaruh 
signifikan terhadap penurunaan kinerja mutu proyek pemeliharan jalan adalah:

-Faktor Material (X2, X3)

-Faktor Sumber Daya Manusia (X9)

\subsection{Saran}

Berdasarkan kesimpulan yang telah diuraikan diatas maka dapat diberikan beberapa saran sebagai berikut :

1. Hasil Penelitian dapat dijadikan pedoman untuk mengurangi penyebab turunnya kinerja mutu pelaksannan proyek pemeliharaan jalan dengan menentukan respon risiko dengan memberikan solusi korektif dan preventif terhadap faktor-faktor risiko yang berpengaruh terhadap kinerja mutu.

2. Penelitian ini dapat dilanjutkan untuk menentukan perbaikan dan strategi untuk mengurangi penyebab turunnya kinerja mutu pada proyek dan perlu dilakukan penelitian lebih lanjut mengenai berapa besar perubahan yang diakibatkan dari turunnya kinerja mutu pekerjaan konstruksi pemeliharaan jalan.

\section{DAFTAR PUSTAKA}

[1] Asiyanto, 2008. Manajemen Risiko Untuk Kontraktor. Jakarta: PT. Pradnya Paramita

[2] Asmarantka, Safira. 2014. Analisis Risiko Yang Berpengaruh Terhadap Kinerja Proyek Pada Pembangunan Hotel Batiq palembang. Jurnal Teknik Sipil dan Lingkungan. Universitas Sriwijaya. Palembang

[3] Fandopa, Riza. 2012. Pengelolaan risiko pada pelaksanaan proyek jalan perkerasan lentur PT. $\mathrm{X}$ dalam rangka meningkatkan kinerja mutu. Thesis Universitas Indonesia. Jakarta

[4] Hardiyatmo, H.C. 2009. Pemeliharaan Jalan Raya Perkerasan Drainase Longsoran. Yogyakarta. Gadjah Mada University Press.

[5] Mulyono, Agus Taufik. 2008. Faktor Dominan yang Mempengaruhi Kekuatan Struktural Perkerasan Jalan di Indonesia. Jurnal Transportasi, FSTPT, Vol. 8 No. 1, hal. 1-14.

[6] Saaty,Thomas L. 2008. Decision Making With The Analytic Hierarchy Proccess. Vol. 1, No. 1, 2008: Hal 83-97.

[7] Sukirman, Silvia. 2003. Beton Aspal Campuran Panas;Edisi 1. Jakarta. Granit

[8] Zuliyanto, Sriyono Dwi .2015. Identifikasi faktor-faktor risiko kontraktor pada pelakasanaan proyek jalan perkerasan lentur (flexible pavement) terhadap kinerja mutu proyek jalan. Thesis. Universitas Atmajaya Yogyakarta. 